\title{
Energy content of Pacific salmon as prey of northern and southern resident killer whales
}

\author{
Sandra M. O'Neill ${ }^{1,3, *}$, Gina M. Ylitalo ${ }^{1}$, James E. West ${ }^{2}$ \\ ${ }^{1}$ Environmental and Fisheries Science Division, Northwest Fisheries Science Center, National Marine Fisheries Service, \\ National Oceanic and Atmospheric Administration, 2725 Montlake Blvd. E., Seattle, WA 98112, USA \\ ${ }^{2}$ Washington Department of Fish and Wildlife, 600 Capitol Way North, Olympia, WA 98501-1091, USA \\ ${ }^{3}$ Present address: Washington Department of Fish and Wildlife, 600 Capitol Way North, Olympia, WA 98501-1091, USA
}

\begin{abstract}
Recovery of depleted species is difficult, but it can be especially complex when the target species interacts strongly with other depleted species. Such is the case for northern and southern resident killer whales Orcinus orca which are listed as 'endangered' under the US Endangered Species Act (ESA) and Canada's Species at Risk Act. These resident killer whales prey heavily on Pacific salmon Oncorhynchus spp., including several 'evolutionarily significant units' also listed under the ESA. In response to concerns that a depleted prey base may affect killer whale recovery, we analyzed proximate composition and calculated caloric content of Pacific salmon to evaluate the importance of salmon species, population, body size, and lipid levels in determining their energy content as prey for killer whales. We sampled all 5 species of Pacific salmon, but emphasized Chinook salmon, a predominant prey of killer whales. Energy density $\left(\mathrm{kcal} \mathrm{kg}^{-1}\right)$ was highly correlated with lipid content, whereas total energy value $\left(\mathrm{kcal} \mathrm{fish}^{-1}\right)$ was determined primarily by fish mass and secondarily by lipid content. These salmon energetics data can be used to provide better precision and estimates on the caloric value of prey to killer whales. To facilitate application of these results to the co-management of salmon and killer whales, we produced a simple relationship that uses fish length to predict total energy of Chinook salmon as prey where population-specific energy densities and fish masses are lacking. Benefits to killer whales from possible salmon fishery closures, or other activities that affect prey availability, will depend on the salmon species and populations involved.
\end{abstract}

KEY WORDS: Pacific salmon $\cdot$ Energy content $\cdot$ Resident killer whale prey

\section{INTRODUCTION}

The preservation and rebuilding of threatened and endangered species is a world-wide concern, as many species and distinct population segments have declined precipitously in the past decades (Hutchings \& Reynolds 2004, Schipper et al. 2008). Rebuilding plans for single species are always challenging, but they are especially so when the target species interacts strongly with other listed species (Williams et al. 2011). For example, in the northeastern Pacific Ocean, killer whales Orcinus orca exist as 3 sym- patric ecotypes, commonly known as resident, transient, and offshore forms, each of which has a distinct diet (Krahn et al. 2002, Ford et al. 2010a). Residents feed on fish and especially Pacific salmon Oncorhynchus spp., whereas transient killer whales feed primarily on marine mammals (Ford 1998). The offshore killer whales are distributed along the outer coast and also eat fish, but they appear to specialize in sharks and other large fishes (Ford et al. 2000, Dahlheim et al. 2008). Krahn et al. (2004) described several populations of eastern North Pacific resident killer whales, including northern and southern resi- 
dent killer whales (NRKW and SRKW, respectively). The NRKW population is found mostly in coastal waters near the middle of Vancouver Island and north to southeastern Alaska, whereas the SRKW population is found primarily farther south, off the southern half of Vancouver Island and in the inland waters of Washington state (Ford et al. 2010b), although there is some overlap in distribution (summarized in Hilborn et al. 2012).

From 1996 to 2001, the SRKW population declined $20 \%$ (from 97 whales to 78), and was listed as endangered under both the Endangered Species Act (ESA) in the United States (NMFS 2005) and the Species at Risk Act (SARA) in Canada (Fisheries and Oceans Canada 2008). The NRKW population also declined during the late 1990s, and was designated as threatened under the SARA (Fisheries and Oceans Canada 2008). Many factors may have contributed to these declines, including vessel and noise disturbances (Holt et al. 2009, Lusseau et al. 2009) and exposure to high levels of persistent organic pollutants (POPs) obtained through their diet (Ross et al. 2000, Rayne et al. 2004, Krahn et al. 2007, 2009). Reduction in populations of the whales' prey has also been hypothesized as a contributing factor in reduced reproduction (Ward et al. 2009) and population declines (Ford et al. 2010a,b).

NRKW and SRKW feed primarily on Pacific salmon, and Chinook salmon $O$. tshawytscha are the predominant prey during the summer and early fall (Ford 1998, Ford \& Ellis 2006, Ford et al. 2010a,b, Hanson et al. 2010). They also capture older (i.e. larger) than average Chinook salmon (Ford \& Ellis 2006) and likely consume both wild and hatchery salmon (Hanson et al. 2010). Other salmon species are sometimes consumed, but much less frequently than would be expected based on their abundance in coastal waters. Chinook salmon achieve the largest body size of the Pacific salmon, commonly reaching 10 to $15 \mathrm{~kg}$, but are currently (and likely also in the past) the least numerous (Quinn 2005). It has been hypothesized that NRKW and SRKW focus their foraging efforts on Chinook salmon to maximize energy intake (Ford \& Ellis 2006). Other possible explanations may be a difference in the whales' ability to detect Chinook salmon (Au et al. 2004) or to catch larger versus smaller fish, or a constraint of their culturally inherited foraging strategies (Ford et al. 2010a).

The abundance of Pacific salmon and especially Chinook salmon has been declining in the southern portion of their range for decades (Nehlsen et al. 1991, Fisher 1994, Slaney et al. 1996, Yoshiyama et al. 1998, Gustafson et al. 2007), resulting in the listing of numerous 'evolutionarily significant units' of Pacific salmon as threatened or endangered under the US Endangered Species Act. While naturally produced salmon have declined in many areas, hatchery production has supplemented many populations (Barnett-Johnson et al. 2007 [Central Valley], NMFS 2008b [Columbia River Basin], PMFC 2011 [Puget Sound]) and may contribute a large fraction of the salmon prey base returning to watersheds within the range of SRKW individuals. In addition to declines in abundance, some evidence suggests that Chinook salmon have declined in body size (Ricker 1981, Bigler et al. 1996). A combination of the decreasing abundance and body size of the primary prey of SRKW could significantly reduce the prey base below levels necessary to meet the energetic requirements of resident killer whales, potentially affecting their persistence and recovery (NMFS 2011).

A better understanding of the variation in caloric content among salmon populations is needed to improve estimates of the available prey base, enhancing the integration of killer whale conservation with salmon management. For example, Williams et al. (2011) noted that the predictions of the total prey requirement of the SRKW population could vary by a factor of 2.3, depending on the values used for whale body size; a factor of 2.9, depending on whether all or none of the diet is composed of Chinook salmon; and a factor of 1.7, depending on whether the caloric values used for Chinook salmon were for 'calorie-rich' or 'lean' fish. Estimating the energetic values of Chinook salmon as prey is complicated by the great diversity in body size and fat content among populations (Healey 1991), but improving the accuracy and precision of this parameter is far more tractable than estimating the body size of the whales or the percent of their diet that is composed of Chinook salmon.

In many large river systems, Chinook salmon breed in discrete locations, and those populations may differ in timing of return from the ocean, body size, and fat content as needed to reach spawning grounds that differ in distance and elevation from the ocean (Ricker 1972, Quinn 2005). Other salmon species also vary in size (Quinn 2005), so additional information on body size and energy density for Chinook salmon and other Pacific salmon is needed to evaluate their value as prey. Currently, most of the energy content data on Pacific salmon are based on fillets (Gilhousen 1980), whereas whales eat whole fish, and the available data are limited in geographic range.

The goal of this study was to determine the energy content of Pacific salmon as prey for resident killer whales using proximate composition and fish mass 
data. We conducted a coast-wide study to assess the energetic content ( $\mathrm{kcal} \mathrm{kg}^{-1}$ and kcal fish ${ }^{-1}$ ) of Chinook salmon over the geographic range in which they would be routinely encountered by NRKW and SRKW. Major population-complexes of sockeye $O$. nerka, coho O. kisutch, pink O. gorbuscha, and chum salmon $O$. keta were also sampled to compare energetic content among Pacific salmon species. Specifically, we (1) quantified differences in energy content among 5 salmon species, (2) tested for differences in energy content among Chinook salmon populations, and (3) evaluated the influence of lipid content and fish size in determining energy density $\left(\mathrm{kcal} \mathrm{kg}^{-1}\right)$ and total energy value $\left(\mathrm{kcal}_{\mathrm{fish}}{ }^{-1}\right)$. Additionally, to facilitate application of the results to the co-management of Chinook salmon and killer whales, we produced a simple predictive relationship between fish length and total energy value for use when population-specific energy density and body mass informa- tion are not available. The results of this study can be used to better assess the energetic value of the prey base available to resident killer whales, a necessary first step in evaluating the potential effects on killer whales of possible salmon fishery closures, or of other activities that affect the availability of salmon species and populations.

\section{MATERIALS AND METHODS}

\section{Sampling design and locations}

We sampled whole bodies of the 5 species of Pacific salmon caught in marine waters or slightly upriver from the mouths of major rivers, at the beginning of their upriver migration, from northern British Columbia to central California (Fig. 1) during summer and early fall (Table 1), encompassing the spatial and tem-

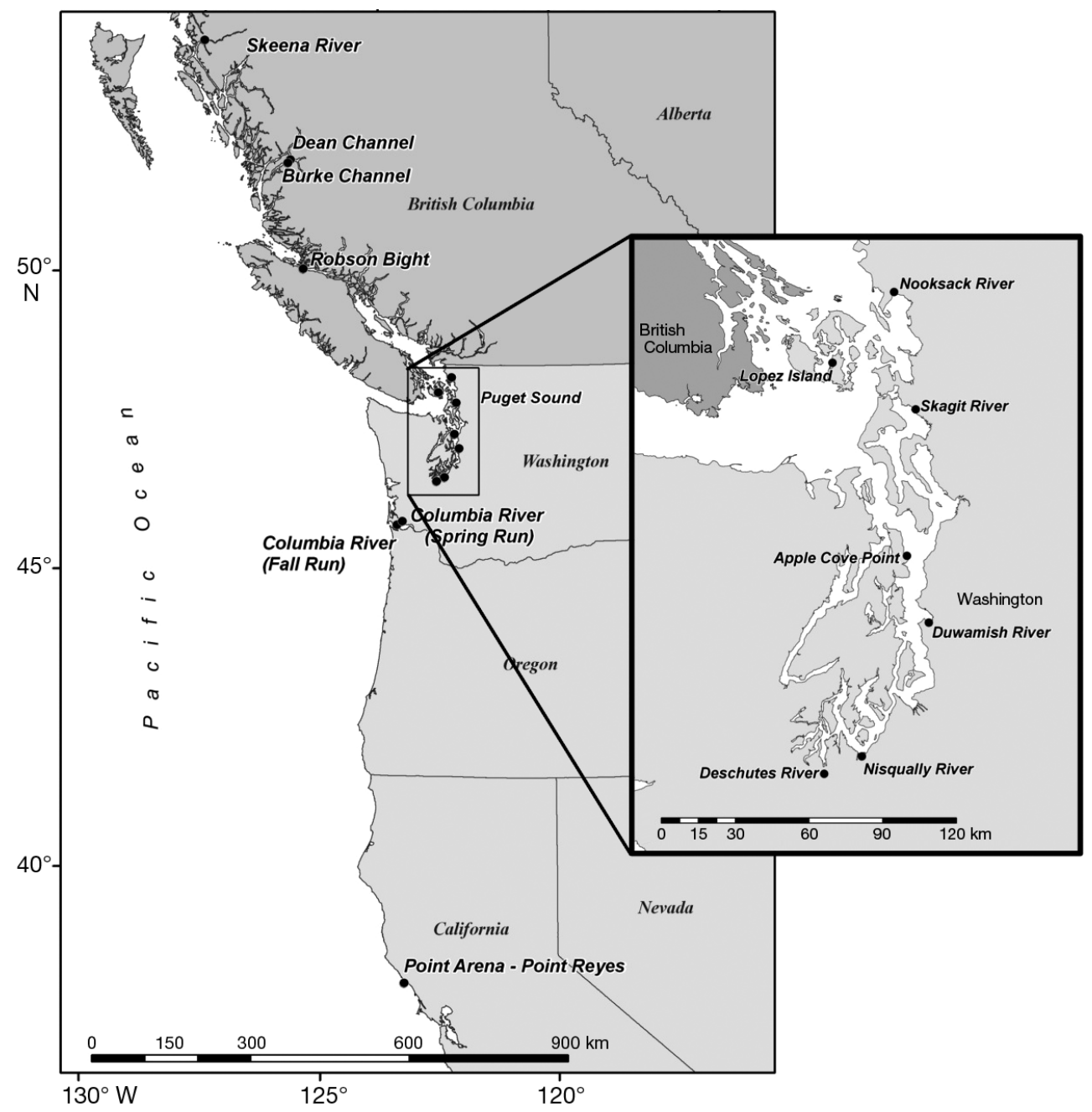

Fig. 1. Oncorhynchus spp. Sampling locations for Pacific salmon 


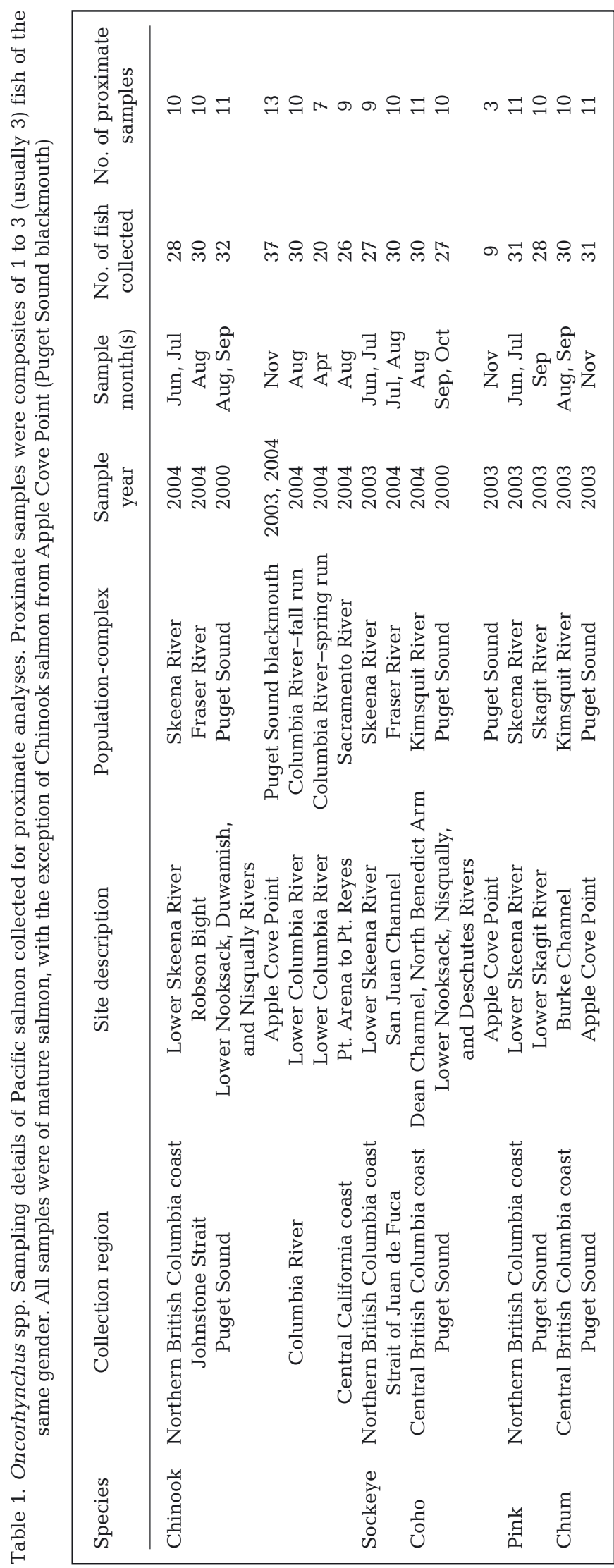

poral summer feeding ranges of NRKW and SRKW. Mature Chinook salmon were collected from 5 regions, including coastal marine sites where NRKW and SRKW feed (Zamon et al. 2007, Ford et al. 2010b) or nearby rivers: (1) north-central coast of British Columbia, near the mouth of the Skeena River; (2) Johnstone Strait, near Robson Bight; (3) Puget Sound, near the mouths of the Nooksack, Duwamish, and Nisqually Rivers, and in Puget Sound's main basin (Apple Cove Point); (4) the lower Columbia River (spring and fall runs), and central coast of California, between Pt. Arena and Pt. Reyes (Table 1). Sampling bracketed the peak run-timing for each population, when these species are most abundant in near-shore waters.

Each of the other Pacific salmon species was collected in 2 geographically separated regions, one in the more northern end of the NRKW and SRKW summer feeding range and the other in the center of their range. Sockeye salmon were sampled from the north-central coast of British Columbia, near the mouth of the Skeena River, and from the Strait of Juan de Fuca, near Lopez Island (Fig. 1). Pink salmon were also sampled near the mouth of the Skeena River and in Puget Sound near the mouth of the Skagit River. Coho and chum salmon were sampled from the central coast of British Columbia (Dean and Burke channels) and Puget Sound (both species from Apple Cove Point as well as coho salmon near the mouths of the Nooksack, Nisqually, and Deschutes Rivers).

All fish were randomly sampled from commercial or test-fisheries targeting mature salmon (Table 1), usually 3 times, bracketing the peak of the run. Except for Chinook salmon collected from Johnstone Strait, the Columbia River, and the California coast, the population-complex associated with each sampling site (Table 1) was based on the locations and return time for specific populations. Chinook salmon caught at river mouths in Puget Sound (all mature) were treated as 1 population (i.e. Puget Sound), whereas the marine-caught fish (Apple Cove Point) were immature resident fish, referred to regionally as blackmouth, and were treated as a separate population (i.e. Puget Sound blackmouth). All marine and in-river-caught Puget Sound coho salmon were mature and were treated as 1 population.

The population-complexes of Chinook salmon from Johnstone Strait, the Columbia River, and the California coast were based on genetic analyses that use a coast-wide data set of genotypes at 13 microsatellite loci developed by a consortium of laboratories (Genetic Analyses of Pacific Salmonids [GAPS]; see Seeb et al. [2007]) to identify their origin. Chinook 
salmon caught in Robson Bight mostly originated from Fraser River (64\% from South Thompson stock) and are hereafter referred to as the Fraser River population-complex but they also included fish from the east coast of Vancouver Island (14\%) and Puget Sound $(14 \%)$. The fall and spring runs of Chinook salmon from the Columbia River were treated as separate populations, consistent with their designation as separate evolutionarily significant units for conservation, and the differences in their size, migration timing, marine distribution, and other features (Myers et al. 1998). Genetic sampling of the Columbia River fish confirmed that the spring population-complex consisted almost exclusively (>94\%) of lower Columbia spring-run fish, and the fall population-complex consisted mostly of mid-Columbia Tule ( $60 \%)$, lower Columbia fall (25\%), and upper Columbia summer/ fall stocks $(5 \%)$. Chinook salmon collected off the coast of California were mostly ( $73 \%$ ) from the Sacramento and San Joaquin population-complex, but included a few fish from the northern California Coast (11\%) and from the Oregon coast or the Columbia River $(16 \%)$, hereafter referred to as the Sacramento River population.

\section{Sample preparation}

Whole salmon were transported on ice to the laboratory where they were measured for fork length (mm) and mass ( $\mathrm{g}$ wet weight). The fish were then placed in plastic bags and frozen at $-30^{\circ} \mathrm{C}$ until tissues were processed for proximate analyses. Whole bodies of frozen salmon were sawed into $38 \mathrm{~mm}$ wide strips, then passed through a meat grinder with a $6.35 \mathrm{~mm}$ hole plate, and homogenized for approximately 3 to $5 \mathrm{~min}$ in an industrial-size food mixer. Approximately $100 \mathrm{~g}$ of homogenized tissue from each fish was stored at $-30^{\circ} \mathrm{C}$ until proximate composition was determined.

\section{Proximate analyses}

A total of 446 fish, combined into 155 composite samples, were processed (Table 1). Species-population composite samples were created from tissue of males or females from a collection site and analyzed for proximate composition, including moisture, protein, lipid, and ash content. First, $100 \mathrm{~g}$ subsamples of individual fish were dried at $105^{\circ} \mathrm{C}$ to a constant weight to determine the percentage of solids (ratio of dry mass to wet mass) and the percentage of water
(100 - the percent of solids). Composite samples for proximate analyses were then created for each sampling site by combining equal amounts of dried tissue from 2 or 3 randomly selected fish of the same sex.

The lipid content of the dry composite tissue sample was determined gravimetrically on methylene chloride Soxhlet-extracted tissues (AOAC International 2000). Percent nitrogen $(\mathrm{N})$ and protein $(\mathrm{N} \times$ 6.25) content for composite samples were measured using a FP-2000 nitrogen/protein analyzer (LECO Corporation) by the AOAC official method 968.06 (AOAC International 2000). Ash content was determined by combustion using the AOAC official methods 942.05 (AOAC International 2000). Carbohydrates were not measured because they contribute an insignificant amount of energy (e.g. $<0.5 \%$ of the somatic tissue) in salmon tissue (Jonsson et al. 1991, 1997). To determine percent lipid, protein, and ash by wet mass, the proportions of dry tissue composed of lipid, protein, and ash in a sample were multiplied by the average percent of solids from that sample.

\section{Energy content}

The kilocalories of lipid and protein tissues were estimated separately for each composite whole body sample by multiplying the lipid and protein wet mass (percent tissue $\times$ average mass of fish in the composite) by the average energy equivalents in each tissue type $\left(\right.$ lipid $=9 \mathrm{kcal} \mathrm{g}^{-1}$, protein $=4 \mathrm{kcal} \mathrm{g}^{-1}$ ). Total energy ( $\mathrm{kcal}^{\mathrm{fish}}{ }^{-1}$ ) was then estimated by summing the kilocalories for lipid and protein tissues. The energy density $\left(\mathrm{kcal} \mathrm{kg}^{-1}\right)$ for each composite sample was calculated by dividing the total kilocalories of the composite sample by the average mass of fish in the composite.

\section{Statistical analyses}

A 1-way analysis of variance (ANOVA) or KruskalWallis test was used to test for significant differences in fish size (length or mass), proximate values (percent lipids, protein), and energy content ( $\mathrm{kcal} \mathrm{kg}^{-1}$ and kcal fish ${ }^{-1}$ ) among species groups, and among Chinook salmon population-complexes, depending on whether the data for specific tests met the normality and constant variance assumptions of ANOVA (SigmaPlot v. 11.0, 2011). Holm-Sidak and Dunn's post hoc multiple range tests were run for all significant differences in ANOVA and Kruskal-Wallis tests, respectively. 
Variation in energy content by species and population was modeled using stepwise linear regression models (SPSS v. 12.0, 2011) with the general goal of deriving a predictive model to maximize the variation explained with as few factors as possible. Significant independent variables or interactions $(p<0.05)$ were only included in the final model if they explained $>4 \%$ of the variation in the dependent variable. All final models were re-run with backward steps to confirm the robustness of the results. Data were transformed as needed (ln-normalized values of kilocalories and fish mass and arcsine-square-roottransformed percent lipid values) to meet assumptions of linearity and normally distributed errors.

The total energy of a fish ( $\mathrm{kcal} \mathrm{fish}^{-1}$ ) results from the combination of its mass-specific energy or energy density, and its mass. These analyses were intended to produce predictive regression models for energy density and total energy using the relatively easily measured independent variables: lipids to predict energy density and fish mass and lipids to predict total energy. Using linear regression, we first determined the relationship between lipid concentration and energy density for: (a) the mature Pacific salmon representing all 5 species combined, and then separately for (b) all 7 populations of Chinook salmon samples combined, including immature fish.

(a) Pacific salmon:

$\mathrm{kcal} \mathrm{kg}^{-1}=\beta_{0}+\beta_{1}(\%$ Lipids $)+\varepsilon$

(b) Chinook salmon:

$\mathrm{kcal} \mathrm{kg}^{-1}=\beta_{0}+\beta_{1}(\%$ Lipids $)+\varepsilon$

where $\beta$ represents the regression parameters (intercept and the slope of the line-of-best fit) and $\varepsilon$ represents the error.

Second, we modeled total energy as a function of fish mass and lipids for (a) and (b) as defined earlier in this section.

(a) Pacific salmon:

$\mathrm{kcal} \mathrm{fish}^{-1}=\beta_{0}+\beta_{1}$ (mass $)+\beta_{2}(\%$ Lipids $)+$ $\beta_{3}$ (mass $\times \%$ Lipids) $+\varepsilon$

(b) Chinook salmon:

$\mathrm{kcal} \mathrm{fish}^{-1}=\beta_{0}+\beta_{1}$ (mass $)+\beta_{2}(\%$ Lipids $)+$

$\beta_{3}($ mass $\times \%$ Lipids $)+\varepsilon$

Third, we considered total energy of the fish as the response variable and estimated the contributions of fish mass and (a) species and (b) Chinook salmon population as categorical variables, as well as their interaction. These models used fish species and Chinook populations as easily observed proxies for lipid and energy density, which are much more difficult to measure in the field and are described as: (a) Pacific salmon:

$$
\begin{array}{r}
\text { kcal fish }{ }^{-1}=\beta_{0}+\beta_{1}(\text { mass })+\sum_{i}^{5} \beta_{i}\left(\mathrm{~S}_{i}\right)+ \\
\beta_{3}(\text { mass } \times \% \text { Lipids })+\varepsilon
\end{array}
$$

(b) Chinook salmon:

$$
\begin{array}{r}
\text { kcal fish }{ }^{-1}=\beta_{0}+\beta_{1}(\text { mass })+\sum_{i}^{7} \beta_{i}\left(P_{i}\right)+ \\
\beta_{3}(\text { mass } \times \% \text { Lipids })+\varepsilon
\end{array}
$$

where $\mathrm{S}_{i}$ is one of 5 Pacific salmon species and $P_{i}$ is one of 7 Chinook salmon population-complexes.

Furthermore, we omitted lipids in the linear regression models that estimated the contribution of fish mass and species (or Chinook salmon population) to the total energy value, because some species (or populations) exhibited unique lipid and fish mass characteristics. For example, all Chinook salmon were larger and fattier than pink salmon. In addition, in no case was the species (or population) interaction with fish mass significant. Hence, intercept differences were used to describe species-specific (and Chinook salmon population-specific) relationships between total energy and fish mass.

Finally, to facilitate application of the information in this study to the management of Chinook salmon, we used linear regression to model a predictive relationship between fish length and total energy for those situations when fish mass is not available.

Chinook salmon:

$$
\text { kcal fish }{ }^{-1}=\beta_{0}+\beta_{1}(\text { fish length })+\varepsilon
$$

\section{RESULTS}

\section{Fish size}

\section{Species comparisons}

Other than the immature blackmouth, the Chinook salmon were significantly longer and heavier (800 mm, $7807 \mathrm{~g}$ wet mass) than the other salmon species; they were followed by chum salmon (698 $\mathrm{mm}, 4303 \mathrm{~g})$ which were also longer but not heavier than coho salmon (631 mm, $3556 \mathrm{~g}$ ) (Table 2; Kruskal-Wallis on fish lengths, $H=289.3$, df $=4$, p < 0.001; Kruskal-Wallis on fish mass, $H=305.4$, df $=4$, $\mathrm{p}<0.001$; Dunn's test). Coho salmon were similar in length but heavier than sockeye salmon (O. nerka; $579 \mathrm{~mm}, 2396 \mathrm{~g}$ ), but were longer and heavier than pink salmon (O. gorbuscha; 538 mm, 1858 g). No other significant differences were observed. 
Table 2. Oncorhynchus spp. Mean $( \pm \mathrm{SE})$ and ranges of fork length and fish mass of Pacific salmon species used to estimate energy content. All fish were mature, except the Puget Sound blackmouths. N: total number of fish collected. Significant differences in fork length and fish mass among species are noted by superscripted numbers (1 to 4 ). Significant differences ( $p<0.05$ ) in fork length and fish mass among mature Chinook salmon population-complexes are noted by superscripted letters from a to $\mathrm{C}$

\begin{tabular}{|c|c|c|c|c|c|c|}
\hline \multirow[t]{2}{*}{ Species } & \multirow[t]{2}{*}{ Population-complex } & \multirow[t]{2}{*}{$\mathrm{N}$} & \multicolumn{2}{|c|}{ Fork length $(\mathrm{mm})$} & \multicolumn{2}{|c|}{$\longrightarrow$ Mass $(g)$} \\
\hline & & & Mean $\pm \mathrm{SE}$ & Min-max & Mean $\pm \mathrm{SE}$ & Min-max \\
\hline \multirow{8}{*}{$\begin{array}{l}\text { Chinook } \\
\text { (O. tshawytscha) }\end{array}$} & Skeena River & 28 & $815 \pm 18^{\mathrm{a}}$ & $655-1010$ & $7786 \pm 521.2^{\mathrm{a}, \mathrm{b}}$ & $3772-13766$ \\
\hline & Fraser River & 30 & $834 \pm 23^{\mathrm{a}}$ & $615-1344$ & $8655 \pm 588.7^{\mathrm{a}, \mathrm{b}}$ & $3062-17055$ \\
\hline & Puget Sound & 32 & $786 \pm 9.3^{\mathrm{a}}$ & $686-885$ & $6462 \pm 209.7^{\mathrm{b}, \mathrm{c}}$ & $4088-9512$ \\
\hline & Puget Sound blackmouth & 37 & $492 \pm 18$ & $305-667$ & $1921 \pm 186.6$ & $409-4081$ \\
\hline & Columbia River (fall run) & 30 & $841 \pm 14^{\mathrm{a}}$ & $609-1000$ & $9891 \pm 477.4^{\mathrm{a}}$ & $3825-15486$ \\
\hline & Columbia River (spring run) & 20 & $685 \pm 16^{b}$ & $570-836$ & $5059 \pm 385.8^{\mathrm{c}}$ & 2449-8686 \\
\hline & Sacramento River & 26 & $800 \pm 18^{a}$ & $678-987$ & $8215 \pm 701.2^{\mathrm{b}, \mathrm{c}}$ & $4077-16063$ \\
\hline & All Chinook (mature only) & 166 & $800 \pm 7.8^{1}$ & $570-1344$ & $3807 \pm 233.3^{1}$ & 2249-17055 \\
\hline \multirow[t]{3}{*}{ Sockeye $(O$. nerka) } & Skeena River & 27 & $607 \pm 8.4$ & $491-682$ & $2689 \pm 110.2$ & 1343-3917 \\
\hline & Fraser River & 30 & $553 \pm 4.1$ & $518-610$ & $2132 \pm 61.5$ & $1601-3051$ \\
\hline & All sockeye & 57 & $579 \pm 5.7^{3,4}$ & $491-682$ & $2396 \pm 71.3^{3}$ & $1343-3917$ \\
\hline \multirow[t]{3}{*}{ Coho (O. kisutch) } & Kimsquit River & 30 & $678 \pm 10.8$ & $575-764$ & $4426 \pm 22.7$ & $2220-6521$ \\
\hline & Puget Sound & 36 & $592 \pm 8.6$ & $490-705$ & $2832 \pm 140.5$ & $1582-4526$ \\
\hline & All coho & 66 & $631 \pm 8.6^{3}$ & $490-764$ & $3556 \pm 161.1^{2}$ & $1582-6521$ \\
\hline \multirow[t]{3}{*}{ Pink (O. gorbuscha) } & Skeena River & 31 & $535 \pm 4.9$ & $492-595$ & $1919 \pm 48.8$ & $1570-2597$ \\
\hline & Puget Sound & 28 & $540 \pm 10.1$ & $385-630$ & $1790 \pm 54.2$ & $1161-2353$ \\
\hline & All pink & 59 & $538 \pm 5.4^{4}$ & $385-630$ & $1858 \pm 37.0^{3}$ & 1161-2597 \\
\hline \multirow[t]{3}{*}{ Chum (O. keta) } & Kimsquit & 30 & $714 \pm 7.0$ & $642-794$ & $4627 \pm 156.0$ & $3122-7046$ \\
\hline & Puget Sound & 31 & $681 \pm 11$ & $576-825$ & $3793 \pm 221.2$ & $2315-6924$ \\
\hline & All chum & 61 & $698 \pm 6.9^{2}$ & $576-825$ & $4203 \pm 145.3^{2}$ & $2315-7046$ \\
\hline
\end{tabular}

Chinook population-complex comparisons

The average size of Chinook salmon varied from 685 to $841 \mathrm{~mm}$ and 5059 to $9891 \mathrm{~g}$, with most of the variation among populations associated with the Columbia River spring population (Table 2; KruskalWallis on fish lengths, $H=38.52, \mathrm{df}=5, \mathrm{p}<0.001$; Kruskal-Wallis on fish mass, $H=43.99, \mathrm{df}=5, \mathrm{p}<$ 0.001; Dunn's test), being shorter $(685 \mathrm{~mm})$ than all other populations and lighter (5059 g) than all populations except Puget Sound and Sacramento fish. The Puget Sound blackmouth were considerably smaller (average $=492 \mathrm{~mm}, 1921 \mathrm{~g}$ ) than all other Chinook salmon population-complexes, but they were excluded from the above analysis because they were immature.

\section{Proximate analyses}

Species comparisons

The lipid contents of sockeye $(11.3 \%)$ and mature Chinook salmon $(10.5 \%)$ did not differ from each other, but they were higher than those of pink $(4.8 \%)$ and chum (3.1\%) salmon (Table 3; Kruskal-Wallis on percent lipid, $H=89.85$, df $=4, \mathrm{p}<0.001$; Dunn's test). Coho salmon had an intermediate lipid value
$(6.8 \%)$, which was lower than that of sockeye, not significantly different from that of Chinook or pink salmon, but higher than that of chum salmon. No other significant differences were observed.

Among mature fish, the average percent protein values ranged from 17.8 to $19.6 \%$, varying slightly among species (Table 3; ANOVA, $F=16.49$, df $=4$, p $<0.001)$. The highest average percent protein values were observed in Chinook, sockeye, and coho salmon $(19.6,19.4$, and $19.3 \%$, respectively); these did not differ significantly from each other (HolmSidak test). The average protein value for chum salmon $(18.8 \%)$ was significantly lower than that for Chinook but not significantly lower than for sockeye or coho salmon. Pink salmon had significantly less protein $(17.8 \%)$ than any other species.

\section{Chinook salmon population-complex comparisons}

Lipid content also varied among the Chinook salmon population-complexes (Table 3; ANOVA, $F=34.46$, $\mathrm{df}=6,63, \mathrm{p}<0.001)$. The Columbia River spring run $(14.8 \%)$ had significantly higher values than any other Chinook salmon populations, except the Skeena River (13.1\%). Skeena River fish had similar lipid values to those of Fraser River (12.4\%) and Sacramento River populations (12.0\%; Holm-Sidak test). Interme- 
Table 3. Oncorhynchus spp. Means ( \pm SD) and ranges of percent lipid, protein, and moisture of composite samples of Pacific salmon used to estimate energy content. N: number of composite samples. Percent ash ranged from 1.63 to 3.50. Significant differences in lipid and protein contents are noted by superscripted numbers (1 to 4) for species comparisons (mature fish only) and superscripted letters (a to d) for comparisons among Chinook salmon population-complexes. All fish were mature, except the Puget Sound blackmouths

\begin{tabular}{|c|c|c|c|c|c|c|c|c|}
\hline \multirow[t]{2}{*}{ Species } & \multirow[t]{2}{*}{ Population-complex } & \multirow[t]{2}{*}{$\mathrm{N}$} & \multicolumn{2}{|c|}{ Percent lipid } & \multicolumn{2}{|c|}{ Percent protein } & \multicolumn{2}{|c|}{ Percent moisture } \\
\hline & & & Mean \pm SD & $\begin{array}{c}\text { Range } \\
(\min -\max )\end{array}$ & Mean \pm SD & $\begin{array}{c}\text { Range } \\
(\min -\max )\end{array}$ & Mean $\pm \mathrm{SD}$ & $\begin{array}{c}\text { Range } \\
\text { (min-max) }\end{array}$ \\
\hline \multirow{8}{*}{$\begin{array}{l}\text { Chinook } \\
\text { (O. tshawytscha) }\end{array}$} & Skeena River & 10 & $13.1 \pm 1.1^{\mathrm{a}, \mathrm{b}}$ & $11.6-14.5$ & $18.6 \pm 0.6^{\mathrm{c}}$ & $17.8-19.6$ & $66.1 \pm 1.2$ & $63.7-68.0$ \\
\hline & Fraser River & 10 & $12.4 \pm 1.6^{\mathrm{b}}$ & $9.0-14.5$ & $19.9 \pm 0.5^{\mathrm{b}}$ & $19.0-20.8$ & $66.1 \pm 1.5$ & $64.3-69.6$ \\
\hline & Puget Sound & 11 & $6.1 \pm 0.9^{\mathrm{d}}$ & $5.2-7.6$ & $20.8 \pm 0.5^{\mathrm{a}}$ & $19.6-21.8$ & $69.9 \pm 1.1$ & $68.8-72.2$ \\
\hline & Puget Sound blackmouth & 13 & $10.0 \pm 2.4^{\mathrm{c}}$ & $6.7-14.9$ & $16.8 \pm 0.6^{\mathrm{d}}$ & $15.7-18.1$ & $70.4 \pm 3.0$ & $65.9-74.7$ \\
\hline & Columbia River (fall run) & 10 & $6.3 \pm 2.0^{\mathrm{d}}$ & $3.5-9.7$ & $19.6 \pm 0.7^{b}$ & $18.3-20.5$ & $70.8 \pm 1.8$ & $67.3-73.7$ \\
\hline & Columbia River (spring run) & 7 & $14.8 \pm 2.1^{\mathrm{a}}$ & $12.6-18.2$ & $18.4 \pm 0.4^{\mathrm{c}}$ & $17.7-19.1$ & $66.1 \pm 0.8$ & $64.5-67.0$ \\
\hline & Sacramento River & 9 & $12.0 \pm 1.5^{\mathrm{bc}}$ & $10.3-14.5$ & $19.7 \pm 0.5^{\mathrm{b}}$ & $18.7-20.2$ & $64.5 \pm 2.1$ & $60.9-67.5$ \\
\hline & All mature Chinook & 57 & $10.5 \pm 3.7^{1,2}$ & $3.5-18.2$ & $19.6 \pm 1.0^{1}$ & $17.1-21.8$ & $67.4 \pm 2.7$ & $60.9-73.7$ \\
\hline \multirow[t]{3}{*}{ Sockeye $(O$. nerka) } & Skeena River & 9 & $10.4 \pm 1.0$ & $8.3-11.7$ & $20.2 \pm 0.6$ & $17.4-19.4$ & $66.4 \pm 0.9$ & $64.8-67.9$ \\
\hline & Fraser River & 10 & $12.1 \pm 2.5$ & $7.9-15.5$ & $18.4 \pm 0.6$ & $19.6-21.4$ & $65.6 \pm 1.2$ & $63.9-67.3$ \\
\hline & All sockeye & 19 & $11.3 \pm 2.1^{1}$ & $7.9-15.5$ & $19.4 \pm 1.1^{1,2}$ & $17.4-21.4$ & $66.0 \pm 1.1$ & $63.9-67.9$ \\
\hline \multirow[t]{3}{*}{ Coho (O. kisutch) } & Kimsquit River & 11 & $7.2 \pm 0.6$ & $6.5-8.8$ & $19.4 \pm 0.9$ & $18.2-21.0$ & $70.2 \pm 0.9$ & $68.7-71.8$ \\
\hline & Puget Sound & 13 & $6.6 \pm 0.5$ & $5.9-7.6$ & $19.3 \pm 0.7$ & $18.2-20.6$ & $69.8 \pm 0.8$ & $68.6-71.3$ \\
\hline & All coho & 24 & $6.8 \pm 0.6^{2,3}$ & $5.9-8.8$ & $19.3 \pm 0.8^{1,2}$ & $18.2-21.0$ & $70.0 \pm 0.8$ & $68.6-71.8$ \\
\hline \multirow[t]{3}{*}{ Pink (O. gorbuscha) } & Skeena River & 11 & $5.6 \pm 1.5$ & $3.6-9.4$ & $17.8 \pm 0.5$ & $17.1-18.5$ & $72.7 \pm 2.2$ & $68.5-75.2$ \\
\hline & Puget Sound & 10 & $3.9 \pm 0.9$ & $2.8-5.8$ & $17.8 \pm 0.7$ & $16.8-19.3$ & $73.8 \pm 1.6$ & $71.0-76.1$ \\
\hline & All pink & 21 & $4.8 \pm 1.5^{3,4}$ & $2.8-9.4$ & $17.8 \pm 0.6^{3}$ & $16.8-19.3$ & $73.2 \pm 2.0$ & $68.5-76.1$ \\
\hline \multirow[t]{3}{*}{ Chum (O. keta) } & Kimsquit & 10 & $2.9 \pm 0.6$ & $2.0-4.2$ & $18.8 \pm 1.1$ & $17.1-21.0$ & $74.2 \pm 1.5$ & $72.3-76.7$ \\
\hline & Puget Sound & 11 & $3.2 \pm 1.1$ & $1.5-5.1$ & $18.7 \pm 0.9$ & $17.7-20.9$ & $74.2 \pm 1.9$ & $71.2-77.6$ \\
\hline & All chum & 21 & $3.1 \pm 0.9^{4}$ & $1.5-5.1$ & $18.8 \pm 1.0^{2}$ & $17.1-21.0$ & $74.2 \pm 1.7$ & $71.2-77.6$ \\
\hline
\end{tabular}

diate lipid values were observed for the Puget Sound blackmouth $(10.0 \%)$; these were not significantly different from values for the Sacramento population but were significantly higher than values for the Columbia River fall run (6.3\%) and Puget Sound mature fish $(6.1 \%)$. No other significant differences in lipid values of Chinook salmon were observed.

The protein values were significantly higher for Puget Sound Chinook salmon (mature: $20.8 \%$ ) than for other populations, followed by the Fraser River, Sacramento River, and Columbia River fall runs, ranging from 19.9 to $19.6 \%$ (Table 3 ; ANOVA, $F=$ 64.196, $\mathrm{df}=6,63, \mathrm{p}<0.001$; Holm-Sidak test). All these values were significantly higher than those for the Skeena River (18.6\%) and Columbia River spring run fish $(18.4 \%)$. Most notably, the immature Puget Sound blackmouth had significantly lower average protein values $(16.8 \%)$ than the other mature Chinook populations.

\section{Energy content}

Species comparisons

The average energy density ( $\mathrm{kcal} \mathrm{kg}^{-1}$ ) of mature salmon varied among species (Kruskal-Wallis, $H=$
95.42, df $=4, \mathrm{p}<0.001)$. Sockeye and Chinook salmon had similarly high energy densities (averages $=1794$ and $1724 \mathrm{kcal} \mathrm{kg}^{-1}$; Fig. 2; Dunn's test), these were significantly higher than values for coho salmon (average $=1389 \mathrm{kcal} \mathrm{kg}^{-1}$ ), followed by those of pink and chum salmon, with similarly low energy densities (averages $=1143$ and $1026 \mathrm{kcal} \mathrm{kg}^{-1}$ ). Energy density was highly correlated (positively) with lipid content (Fig. 3a; $\mathrm{r}^{2}=0.99 ; F=9907$, df $=1,140, \mathrm{p}<$ $0.001)$, regardless of species, and was predicted by the equation:

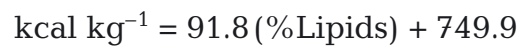

The total energy value (kcal fish ${ }^{-1}$ ) of mature Pacific salmon species was highly correlated with fish mass and lipid content, accounting for 89 and $10.6 \%$ of the observed variation (linear regression on $\ln [\mathrm{kcal}]$, with $\ln$ [mass] and arcsine square-root-transformed percent lipids as independent variables $\left[\mathrm{r}^{2}=\right.$ $0.89 ; F=40633, \mathrm{df}=1,139, \mathrm{p}<0.001])$. The total energy value of Pacific salmon is predicted by the equation:

$\ln \left(\mathrm{kcal} \mathrm{fish}^{-1}\right)=1.023[\ln (\operatorname{mass})]+0.057[\arcsin$

$$
\text { square root (\%Lipids) }]+6.33
$$

For all 5 Pacific salmon species, larger fish had more total energy; however, species with higher energy densities had higher kilocalorie levels for a given 


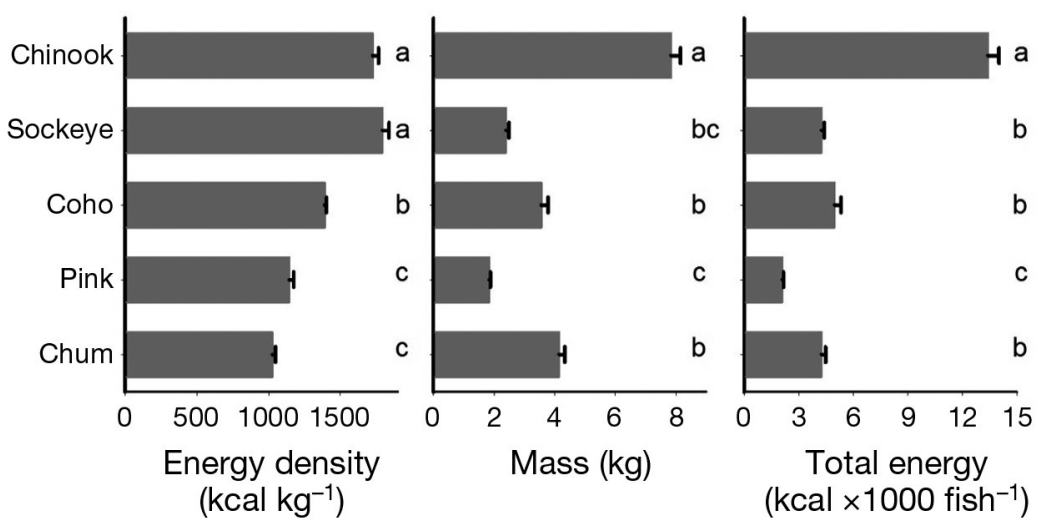

Fig. 2. Oncorhynchus spp. Average $( \pm \mathrm{SE})$ energy density, mass, and total energy of whole-body samples of mature Pacific salmon. Significant differences in energy density, fish mass, and total energy (in kcal) among mature Pacific salmon population-complexes are noted by different letters (a to c). See Table 2 for individual species names density, and coho salmon were heavier but lower in energy density than sockeye salmon. The total energy of pink salmon (average $=2101 \mathrm{kcal} \mathrm{fish}^{-1}$ ) was significantly lower than that of any other species; this was a result of its lower mean mass and energy density.

Chinook salmon population-complex comparisons

The energy density and total energy value varied considerably among Chinook population-complexes, due to variation in lipid content and body size. Significantly higher average energy densities ( $\mathrm{kcal} \mathrm{kg}^{-1}$ ) were mass (Fig. 3b; $\mathrm{r}^{2}=0.96$ for the full model; for $\ln [\mathrm{mass}$, $F=1527.4$, df $=1,138, \mathrm{p}<0.0001$; for species groups, $F=127.1, \mathrm{df}=2,138, \mathrm{p}<0.0001)$. Overall, the total energy value for the 5 species of Pacific salmon is predicted from 3 equations:

$$
\begin{gathered}
\ln \left(\mathrm{kcal} \mathrm{fish}^{-1}\right) \text { Chinook and Sockeye }= \\
0.94[\ln (\text { mass })]+7.56 \\
\ln \left(\mathrm{kcal} \mathrm{fish}^{-1}\right) \text { Coho }= \\
0.94[\ln (\text { mass })]+7.31
\end{gathered}
$$

ln $\left(\mathrm{kcal} \mathrm{fish}^{-1}\right)$ Pink and Chum =

$$
0.94[\ln (\text { mass })]+7.04
$$

Sockeye and Chinook salmon, the most lipid-rich species, had significantly higher total energy for a given mass; pink and chum salmon were the least lipid-rich species and had significantly lower total energy for a given mass (Fig. 3b). Coho salmon showed intermediate energy density, significantly different from all other species (Fig. 3b).

Although the average lipid content and energy density of sockeye and Chinook salmon were similar, Chinook salmon were larger bodied (Fig. 2; KruskalWallis, $H=118.51$, df $=4, \mathrm{p}<0.001$; Dunn's test) and consequently had significantly more total energy than any other salmon species (average = $13409 \mathrm{kcal}$ fish $^{-1}$; Fig. 2; $H=117.37$, df $=4$, p $<0.001$; Dunn's test). The high energy density of sockeye was offset by its smaller size. Coho and chum salmon were heavier than sockeye salmon, but not significantly so, and the 3 species did not differ significantly in total energy (averages $=4982,4265$, and $4264 \mathrm{kcal} \mathrm{fish}^{-1}$, respectively; Fig. 2; Dunn's test). The greater mass of chum salmon was offset by their lower energy
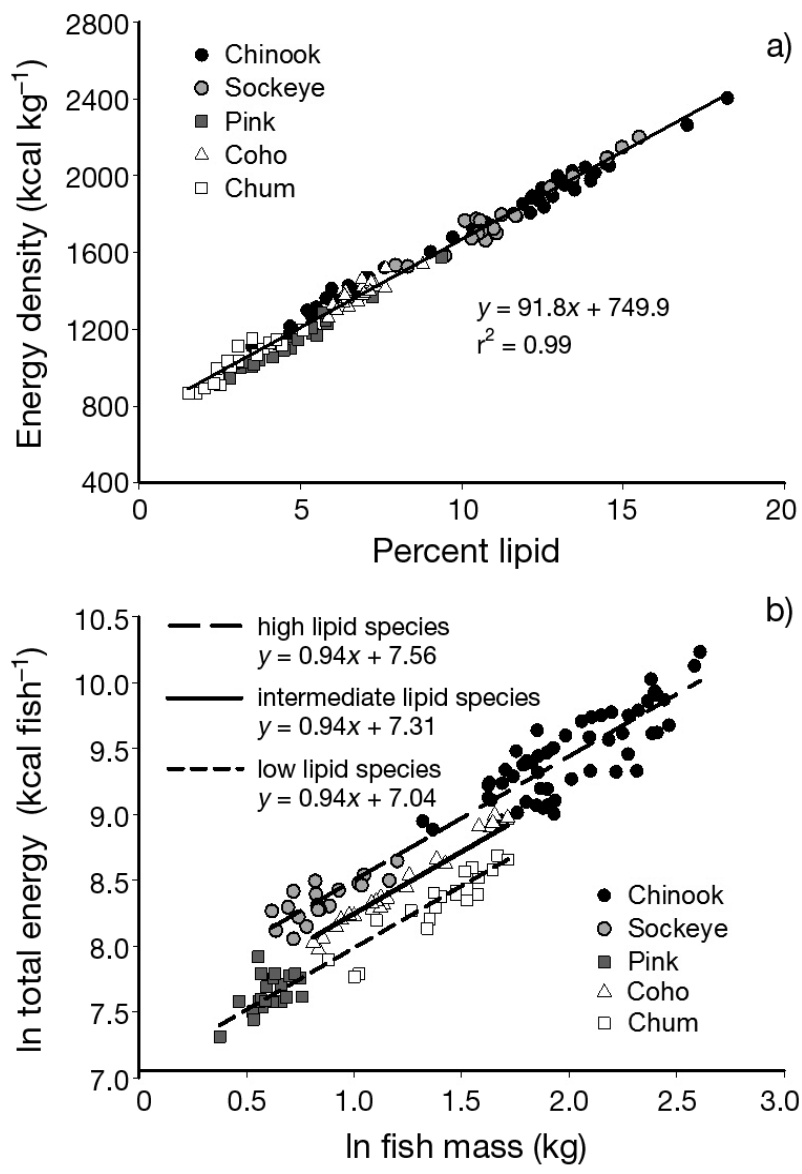

Fig. 3. Oncorhynchus spp. Relationship between (a) lipid content and energy density and (b) fish mass and total energy of 5 species of Pacific salmon. Only mature fish are included. Predicted total energy regression lines are adjusted for species-specific differences associated with lipids. See Table 2 for individual species names 
measured for fattier spring run Columbia River fish and summer/fall run fish returning to the Skeena, Fraser, and Sacramento River (population means ranging from 1863 to 2064) than leaner fall run fish residing in or returning to Puget Sound rivers or the Columbia River (population means ranging from 1353 to 1570; Fig. 4; ANOVA, $F=29.17$, df =6,63, $\mathrm{p}<$ 0.001; Holm-Sidak test). The immature Puget Sound blackmouth had intermediate average energy density values (Fig. 4).

Overall, energy density ( $\mathrm{kcal} \mathrm{kg}^{-1}$ ) was highly correlated with lipid content, for all populations $\left(\mathrm{r}^{2}=\right.$ 0.97; $F=1997$, df = 1,68, p < 0.0001), and could be predicted by the following equation:

$$
\mathrm{kcal} \mathrm{kg}^{-1}=85.6(\% \text { Lipids })+807.7
$$

Total energy ( $\mathrm{kcal}_{\text {fish }}{ }^{-1}$ ) varied significantly among Chinook salmon populations (Kruskal-Wallis, $H=$ 49.38, df $=6, \mathrm{p}<0.001$ ). The immature blackmouth, weighing less than any other Chinook salmon except the Columbia River spring run fish (Fig. 4; KruskalWallis on mean composite weights, $H=49.74$, df $=6$, p $<0.001$ ) and having an intermediate energy density, had the lowest mean total energy value $(3076 \mathrm{kcal}$ fish $^{-1}$ ). However, it was not significantly lower than that of mature fish from Puget Sound or the Columbia River spring run populations (8941 and $10559 \mathrm{kcal}$ fish $^{-1}$, respectively; Dunn's test). Among mature fish, Puget Sound Chinook salmon had a lower mean total energy value than those determined for the other populations, except the Columbia River spring run (Kruskal-Wallis, $H=27.16$, df $=5, \mathrm{p}<0.001$; Dunn's test). The Columbia River spring and fall run fish did not differ significantly in total energy (10 253 vs. $13868 \mathrm{kcal} \mathrm{fish}^{-1}$, respectively) because the higher energy density of the spring fish was offset by the larger size of the fall run fish.

Fish mass and lipid content predicted total energy among Chinook salmon populations, accounting for 85 and $13 \%$ of the observed variation, respectively $\left(\mathrm{r}^{2}=0.98 ; F=1536, \mathrm{df}=2,67, \mathrm{p}<0.001\right)$.

$$
\begin{aligned}
\mathrm{kcal} \mathrm{fish}^{-1}= & 1717.4(\text { fish mass })+ \\
& 594.4(\% \text { Lipids })+6237.7
\end{aligned}
$$

The total energy of Chinook salmon increased with fish mass across all populations; however, the effect of lipid content depended on the population-complex; populations with higher lipid levels (and higher energy densities) had more total energy (in kcal) for a given mass (linear regression on $\mathrm{kcal}_{\mathrm{fish}}{ }^{-1}$, with fish mass as a continuous independent variable and population as a categorical independent variable; $\mathrm{r}^{2}=$ 0.96; $F=1658$, df $=1,66, \mathrm{p}<0.0001$ for fish mass and $F=101.1, \mathrm{df}=6,66, \mathrm{p}<0.0001$ for population group). Chinook salmon from the Skeena, Fraser, Sacramento, Puget Sound blackmouth, and Columbia River spring populations had significantly higher kilocalories for a given mass than the Puget Sound and Columbia River fall populations (Fig. 5b; Holm-Sidak test). The Puget Sound fish had significantly more kilocalories for a given mass than the Columbia River fall fish, but there was little overlap in the range of fish sizes between populations. Overall, when we account for the lipid differences among populations, the total energy value of Chinook salmon for all populationcomplexes is predicted from 3 equations:
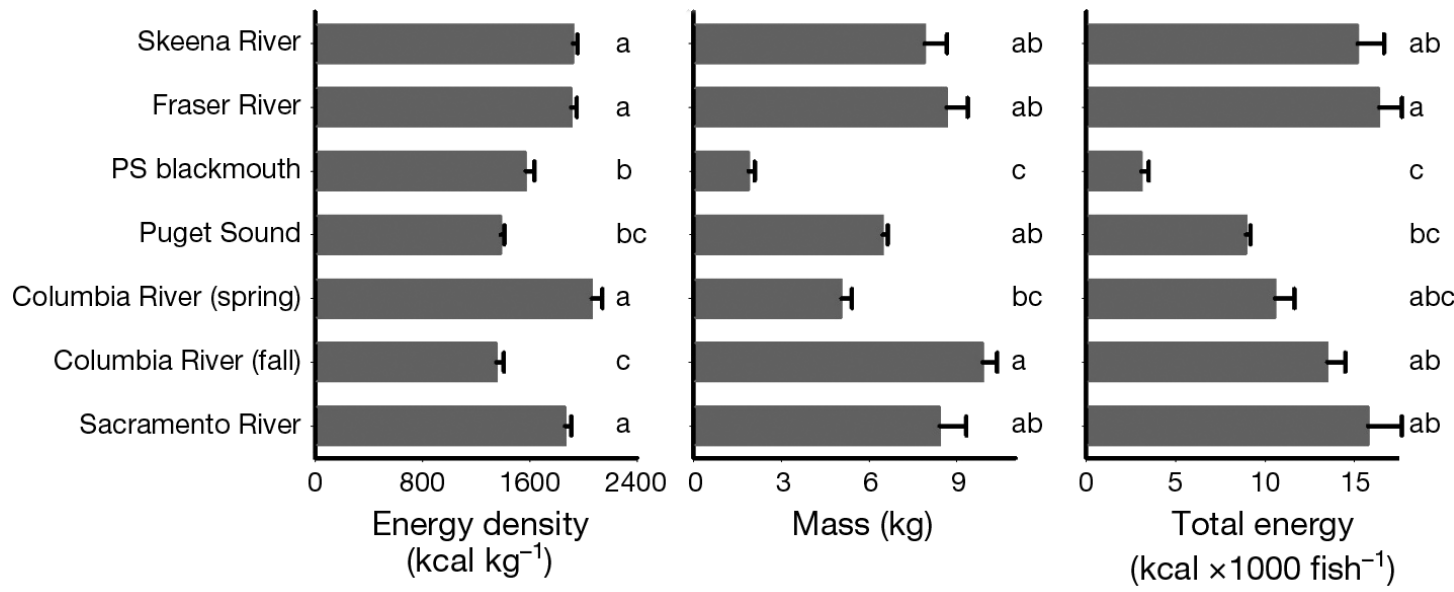

Fig. 4. Oncorhynchus tshawytscha. Average $( \pm \mathrm{SE})$ energy density, mass, and total energy of whole-body samples of Chinook salmon from 7 population-complexes: Skeena River, Fraser River, Puget Sound mature (Puget Sound) and immature residents (Puget Sound blackmouth), Columbia River spring, Columbia River fall, and Sacramento River. Significant differences in energy density, fish mass, and total energy (in kcal) among Chinook salmon population-complexes are noted by different letters (a to c) 

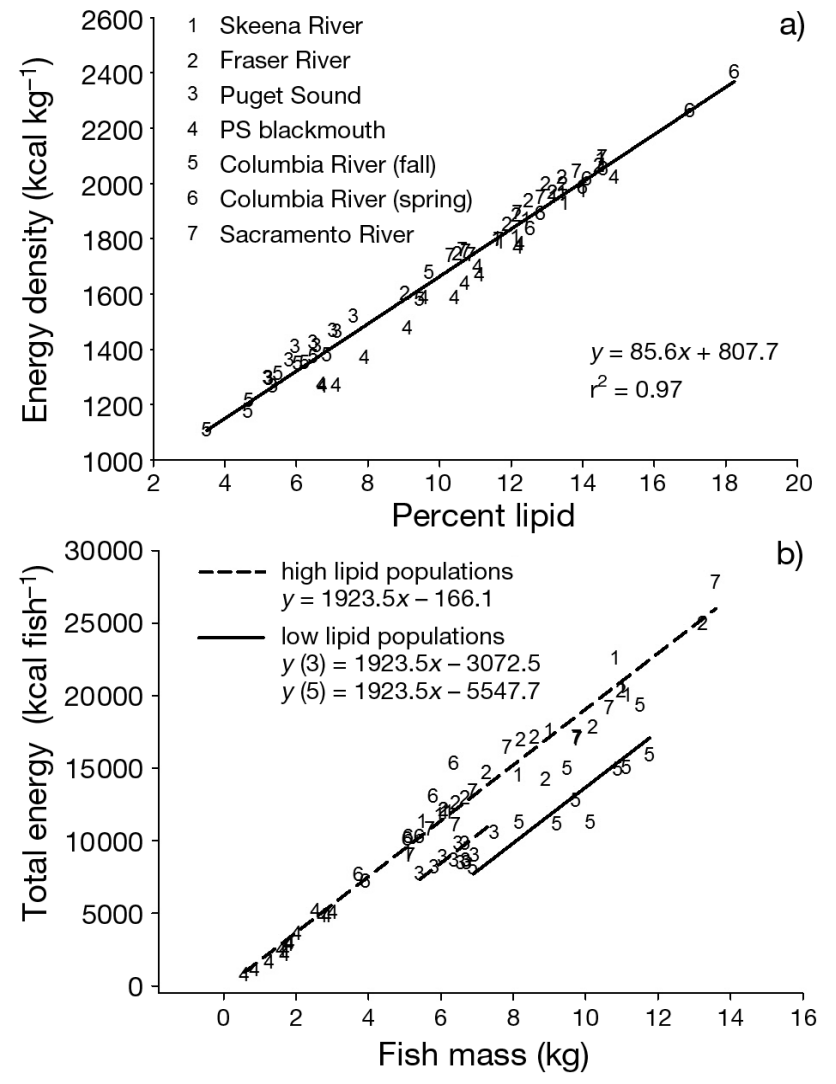

Fig. 5. Oncorhynchus tshawytscha. Relationship between (a) lipid and energy density and (b) fish mass and total energy for Chinook salmon caught in terminal and in-river fisheries. Predicted regression lines are based on linear regression models as described in 'Materials and methods: Statistical analyses'. Numbers along the regression lines refer to populations in the key. Due to the nature of the data, some of the digits used to represent the data points for the individual fish populations overlap

kcal fish ${ }^{-1}(\mathrm{P} 1, \mathrm{P} 2, \mathrm{P} 4, \mathrm{P} 6, \mathrm{P} 7)=$ 1923.5 (fish mass) - 166.1

$$
\begin{aligned}
& \mathrm{kcal} \mathrm{fish}^{-1}(\mathrm{P} 3)=1923.5(\text { fish mass })-3072.5 \\
& \mathrm{kcal} \mathrm{fish}^{-1}(\mathrm{P} 5)=1923.5(\text { fish mass })-5547.7
\end{aligned}
$$

where P1 is Skeena, P2 is Fraser, P3 is Puget Sound, P4 is Puget Sound blackmouth, P5 is Columbia fall, $\mathrm{P} 6$ is Columbia spring, and P7 is Sacramento.

\section{Predictive kcal-fish length relationship for Chinook salmon populations}

Lipid content and fish mass can be used to estimate the total energetic value of Chinook salmon to NRKW and SRKW, but individual fish mass and lipid content data are typically not available for specific salmon populations. To facilitate application of the information in this study to the management of Chinook salmon, a simple predictive relationship between length and total energy content was developed. Fish length predicted total energy value $\left(\mathrm{kcal} \mathrm{fish}^{-1}\right)$ among populations of Chinook salmon, accounting for $91 \%$ of the variation (based on $\ln$ [kcal] and $\ln$ [fish length]; $\left.\mathrm{r}^{2}=0.91 ; F=732.98, \mathrm{df}=1,68, \mathrm{p}<0.001\right)$.

$$
\mathrm{kcal} \mathrm{fish}^{-1}=0.000011 \text { (fish length) }^{3.122}
$$

The relationship between total kilocalories and fish length (Fig. 6) was robust, as evidenced by its consistency when any population was removed from the regression analysis (Table 4). For example, removing the Puget Sound blackmouth (which included many fish that were smaller and younger than fish consumed from May to September in the Salish Sea by NRKW and SRKW) from the analysis shifted the slope of the best-fit regression line slightly but not significantly, and fish length still accounted for most of the observed variation. Excluding the 2 smallest-bodied populations, Puget Sound mature (in-river) and immature (blackmouth), from the regression analyses changed the overall slope of the kcal to fish length relationship significantly (Table 4 ).

To better characterize the effect of populationspecific energy density on the total energy value of Chinook salmon of various lengths, we also modeled energy using the 90th and 10th percentile lipid content values measured for all samples (14.5 and $5.5 \%$, respectively: outer dashed lines in Fig. 6). These lipid values better reflect the high and low energy densities of Chinook salmon populations that occur in terminal marine waters where NRKW and SRKW feed. Using this approach, a fish of typical size $(800 \mathrm{~mm})$ with a $14.5 \%$ lipid content would have a total energy value of $15766 \mathrm{kcal}$, whereas the same-sized fish with a $5.5 \%$ lipid content would have a total energy value of $9602 \mathrm{kcal}$, approximately $40 \%$ lower.

\section{DISCUSSION}

The energy density of salmon was highly correlated with lipid content, but the total energy value was determined primarily by fish size, measured as mass. After accounting for size and lipid differences, salmon species and populations did not vary appreciably in total energy value. Previous studies have documented the importance of fish size and lipid content in determining the energy content of salmon (Gilhousen 1980, Brett 1995, Hendry \& Berg 1999), but ours is the first comprehensive assessment of 


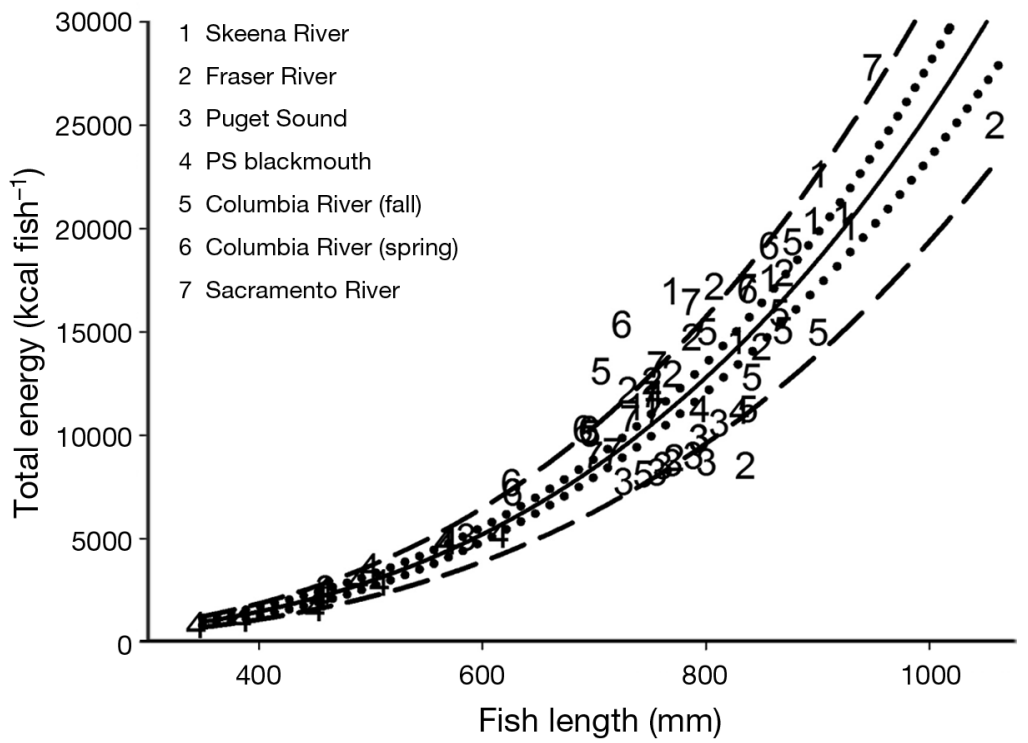

Fig. 6. Oncorhynchus tshawytscha. Relationship between total energy (kcal fish $^{-1}$ ) and fish size (fork length) for Chinook salmon based on 7 population complexes sampled in terminal marine or in-river fisheries. The solid line is the best-fit trend line based on fish length $\left[y=0.000011 \times\left(\right.\right.$ fish length $\left.\left.{ }^{3.122}\right)\right]$. The inner dotted lines depict the predicted $95 \%$ confidence intervals around the trend line. The outer dashed lines depict the hypothesized energy values using the 90th and 10th percentile lipid content measured for all samples, 14.47 and 5.47, respectively. Mature fish were sampled at all sites, except for the Puget Sound blackmouth population-complex, which represented immature fish residing in Puget Sound. Numbers along the regression lines refer to populations in the key. Due to the nature of the data, some of the digits used to represent the data points for the individual fish populations overlap energy content of 5 species of Pacific salmon and multiple populations of Chinook salmon from the standpoint of salmon as prey to apex predators.

Salmon kilocalorie levels are derived mostly from lipids and proteins, because carbohydrates constitute $<0.5 \%$ of the somatic tissue of salmonids (Jonsson et al. 1991, 1997). Variation in energy density among salmon species and populations is almost entirely determined by the degree to which they store lipids, because the protein content, structurally important in muscle development and swimming performance, varies little among mature fish (Brett 1995, Hendry \& Berg 1999). Accordingly, the energy density among salmon species and among Chinook salmon populations was highly correlated with lipid content (Figs. 3a \& 5a, respectively). As salmon mature and migrate upriver, they first burn fat to provide energy for migration and egg development, conserving protein for the subsequent development of secondary sexual characteristics (Hendry \& Berg 1999).

Table 4. Oncorhynchus tshawytscha. Results of linear regression analyses for the measured total energy of Chinook salmon $\left(\mathrm{kcal}_{\mathrm{fish}}{ }^{-1}\right)$ associated with fish length (fork length, $\left.\mathrm{mm}\right)$ using ln-transformed values $[\mathrm{ln} \mathrm{kcal}=($ slope coefficient $\times \ln \mathrm{MCL})+$ intercept coefficient], where MCL is mean composite fish length). The 'full model' regression is the best fit for all 7 Chinook salmon population-complexes sampled (Skeena River, Fraser River, Columbia River fall run, Columbia River spring run, Puget Sound, Puget Sound blackmouth, and Sacramento River). Other models excluded 1 or more of the populations as noted, and the slope that is significantly different $(\mathrm{p}<0.001)$ from the full model is noted by ${ }^{* *}$. N: number of fish sampled

\begin{tabular}{|c|c|c|c|c|c|c|}
\hline Model & $\mathrm{N}$ & $\mathrm{r}^{2}$ & Factor & Estimated coefficient & $\mathrm{SE}$ & $t$-value \\
\hline Full model & 70 & 0.91 & $\begin{array}{l}\text { Intercept } \\
\text { Slope }\end{array}$ & $\begin{array}{r}-11.413 \\
3.122\end{array}$ & $\begin{array}{l}0.765 \\
0.116\end{array}$ & $\begin{array}{r}-14.92 \\
26.91\end{array}$ \\
\hline Excluded Puget Sound blackmouth & 57 & 0.56 & $\begin{array}{l}\text { Intercept } \\
\text { Slope }\end{array}$ & $\begin{array}{r}-7.216 \\
2.494\end{array}$ & $\begin{array}{l}1.974 \\
0.295\end{array}$ & $\begin{array}{r}-3.66 \\
8.44\end{array}$ \\
\hline Excluded Sacramento River & 61 & 0.91 & $\begin{array}{l}\text { Intercept } \\
\text { Slope }\end{array}$ & $\begin{array}{r}-11.061 \\
3.065\end{array}$ & $\begin{array}{l}0.800 \\
0.122\end{array}$ & $\begin{array}{r}-13.83 \\
25.21\end{array}$ \\
\hline Excluded Columbia River (fall run) & 60 & 0.92 & $\begin{array}{l}\text { Intercept } \\
\text { Slope }\end{array}$ & $\begin{array}{r}-11.805 \\
3.184\end{array}$ & $\begin{array}{l}0.803 \\
0.122\end{array}$ & $\begin{array}{r}-14.70 \\
26.06\end{array}$ \\
\hline Excluded Columbia River (spring run) & 63 & 0.93 & $\begin{array}{l}\text { Intercept } \\
\text { Slope }\end{array}$ & $\begin{array}{r}-11.648 \\
3.153\end{array}$ & $\begin{array}{l}0.725 \\
0.110\end{array}$ & $\begin{array}{r}-16.06 \\
28.69\end{array}$ \\
\hline Excluded Fraser River & 60 & 0.92 & $\begin{array}{l}\text { Intercept } \\
\text { Slope }\end{array}$ & $\begin{array}{r}-11.351 \\
3.109\end{array}$ & $\begin{array}{l}0.805 \\
0.122\end{array}$ & $\begin{array}{r}-14.11 \\
25.40\end{array}$ \\
\hline Excluded Puget Sound & 59 & 0.95 & $\begin{array}{l}\text { Intercept } \\
\text { Slope }\end{array}$ & $\begin{array}{r}-12.032 \\
3.224\end{array}$ & $\begin{array}{l}0.630 \\
0.096\end{array}$ & $\begin{array}{r}-19.08 \\
33.65\end{array}$ \\
\hline Excluded Skeena River & 60 & 0.91 & $\begin{array}{l}\text { Intercept } \\
\text { Slope }\end{array}$ & $\begin{array}{r}-11.256 \\
3.096\end{array}$ & $\begin{array}{l}0.842 \\
0.128\end{array}$ & $\begin{array}{r}-13.37 \\
24.19\end{array}$ \\
\hline $\begin{array}{l}\text { Excluded Puget Sound \& } \\
\text { Puget Sound blackmouth }\end{array}$ & 46 & 0.73 & $\begin{array}{l}\text { Intercept } \\
\text { Slope }^{* *}\end{array}$ & $\begin{array}{r}-6.631 \\
2.419\end{array}$ & $\begin{array}{l}1.461 \\
0.219\end{array}$ & $\begin{array}{l}-4.54 \\
11.07\end{array}$ \\
\hline
\end{tabular}


Lipid content in mature salmon populations at river entry is an adaptation for the duration of time spent in freshwater prior to spawning and the arduousness of their upriver migration (Gilhousen 1980, Brett 1995, Quinn 2005), and is correlated with migration length and elevation (Quinn 2005). Two divergent life-history patterns in river migration and maturation have been described for Pacific salmon, resulting in 2 separate behaviors and associated energy content for coastal and interior populations, described by Gilhousen (1980) and reviewed by Brett (1995). Coastal populations, including most pink, chum, coho, and many Chinook salmon, enter freshwater in an advanced state of maturity and spawn in the lower reaches of rivers soon after leaving the sea. These populations store less of their total energy as fat while feeding at sea and have lower lipid levels at river entry. In contrast, interior populations of Chinook salmon are typically in a less advanced state of maturity and have higher fat content when they leave the ocean, and spend more time in freshwater prior to spawning. Sockeye salmon deviate from this dichotomy between low-energy populations near the coast and high-energy interior populations. Some sockeye salmon populations have high energy content when they leave the ocean because they have lengthy migrations but other populations have high energy content despite short migrations because they leave the ocean early in the year and fast for long periods of time prior to spawning (Hodgson \& Quinn 2002). Overall, the lipid content in coastal populations of salmon is generally 2 to $5 \%$ of the somatic tissues $(9 \%$ for downstream sockeye salmon), whereas in upriver, interior spawning populations these values range from 12 to $15 \%$ (Brett 1995).

Consistent with the above-mentioned patterns, we observed high lipid values in sockeye, intermediate values in coho, and lower levels in pink and chum salmon (Table 3). Lipid content in Chinook was similar to that in sockeye salmon (Table 3) but varied widely among population-complexes. The lower lipid contents of the Chinook salmon from Puget Sound and Columbia River fall run fish sampled for this study (mostly lower river stocks) are likely due to the short distances they migrate upstream to spawn. Some of the variation in lipid content among Chinook salmon populations may also be associated with their advancing maturation state, as lipid content declines dramatically as fish move into freshwater and become sexually mature (Shearer et al. 1994, Ewald et al. 1998, Hendry \& Berg 1999). For example, the difference in lipid content between immature (9.9\%) and mature in-river-caught fish (6.1\%) from Puget Sound suggests that the mature fish had started to metabolize their fat reserves for reproduction when sampled. However, all of the in-river-caught fish obtained for this study were silver in color and lacked the sexual dimorphism more evident in mature fish (e.g. hooked snouts). Moreover, mature Chinook salmon caught in the marine waters of Puget Sound had only slightly higher average lipid values (7.6\%; O'Neill unpubl. data) than the in-river fish sampled here. Fish caught in offshore waters, prior to initiating their home migration, would likely have higher lipid content and kilocalorie levels than those observed in this study, but the lower lipid levels in downstream versus upstream migrants would have been observed regardless.

Body size also varied systematically among species (Chinook $>$ chum $>$ coho $>$ sockeye $>$ pink), consistent with information in prior reviews (Quinn 2005). The average fork lengths of fish collected for this study were-Chinook: $800 \mathrm{~mm}$; chum: $698 \mathrm{~mm}$; coho: $631 \mathrm{~mm}$; sockeye: $579 \mathrm{~mm}$; and pink: $538 \mathrm{~mm}$. This is similar to the central tendency in length reported by Quinn (2005) for salmon species along the west coast of North America - Chinook: $871 \mathrm{~mm}$; chum: $683 \mathrm{~mm}$; coho: $643 \mathrm{~mm}$; sockeye: $553 \mathrm{~mm}$; and pink: $413 \mathrm{~mm}$. Although Chinook are larger than other salmon species, we observed considerable variation in body size among populations, as has been documented elsewhere (Healey 1991, Roni \& Quinn 1995, Myers et al. 1998).

As prey to killer whales, fish with more mass have more total energy, although, for a given mass, total energy increased with lipid content (Figs. 3b \& 5b). Chinook salmon had the highest observed total energy value, and pink salmon had the lowest (Fig. 2). Overall, large fish size off-set energy density in determining their total energy value (Figs. $2 \& 4$ ). Assuming that the fish we sampled were representative of the sizes and lipid content of fish available for consumption, killer whales would need to consume approximately 2.7 coho, 3.1 chum, 3.1 sockeye, or 6.4 pink salmon to obtain the equivalent total energy value of 1 Chinook salmon.

Interestingly, the rank of total energy values of salmon as prey to killer whales is the opposite of the rank of their abundance in coastal waters of British Columbia. Chinook salmon are the least abundant (Henderson \& Graham 1998) but offer the highest energy value. Pink salmon are the most abundant (in odd years; Henderson \& Graham 1998) but provide the lowest energy values. Sockeye salmon are generally more abundant than chum, and chum are simi- 
larly abundant to coho salmon in British Columbia (Henderson \& Graham 1998): all 3 of these species provide similar energy values that lie between those of Chinook and pink salmon. Given the frequency of Chinook salmon in the diet of killer whales, and their lower abundance compared to the other Pacific salmon species, resident whales seem to consume salmon in proportion to the energy payoff per fish rather than the salmon species' density.

Our results support the hypothesis by Ford \& Ellis (2006) that the large size and high lipid content of Chinook salmon relative to other species, in combination with their year-round availability in the coastal waters where killer whales feed, explains why they are more prevalent in the diet than other salmon species. Resident killer whales selectively feeding on individual Chinook salmon may maximize their prey profitability, a common foraging strategy in many animals (Stephens \& Krebs 1986, Scheel 1993, Bowen et al. 2002), by consuming prey with the greatest energy value relative to the effort needed to catch it. As demonstrated in this study, prey size and energy density directly affect the total energy value of salmon as prey, with Chinook salmon being the most valuable. However, the profitability of Chinook salmon as prey is also affected by the relative effort needed to capture the various species of salmon. The catchability of Chinook relative to smaller salmon species is unknown; however, several lines of evidence suggest that such differences are not important to the overall profitability of the various salmon species. Resident killer whales may expend more energy pursing Chinook salmon than smaller salmon species because fish swimming speed scales with length, approximately 1 body length $\mathrm{s}^{-1}$ (Quinn 1988). However, mass increases as the cube of length, so longer fish like Chinook salmon will provide considerably more total energy as prey than smaller fish, likely offsetting the cost of capturing faster fish. Moreover, although Chinook salmon should be able to swim faster than the other species of salmon because of their size, they actually migrate more slowly through coastal waters than other schooling salmon species, although at greater depths (Candy \& Quinn 1999). Even at these greater depths, individual Chinook salmon migrating through coastal waters would be detectable by killer whales via echolocation at ranges of $100 \mathrm{~m}$ or more (Au et al. 2004).

Chinook and coho salmon populations vary in marine distributions, but they generally have more coastal marine distributions (as opposed to the open ocean) than other salmon species (Quinn 2005). Conse- quently, Chinook (and coho) salmon are available year-round as prey to resident killer whales in coastal waters, although in the winter months, only immature fish are available. During the summer months, the smallest maturing Chinook salmon provide more total energy as prey than any of the other Pacific salmon species except the largest coho salmon. Killer whales shift to less profitable chum salmon in the fall, but only after the abundance of maturing Chinook in nearshore waters has declined (Ford et al. 2010b, Hanson et al. 2010).

Differences in the energy content among Chinook populations were also observed, associated with size and lipid content (Fig. 4). Mature Puget Sound Chinook salmon were smaller and leaner than other populations and generally provided less total energy. Assuming that the Chinook salmon we sampled were representative of the sizes and lipid content of fish available for consumption, killer whales would have to eat 1.8 and 1.5 times more Puget Sound fish to get the same total energy value obtainable by feeding on Chinook salmon from fall runs of Fraser River or Columbia River, respectively, possibly explaining the predominance of the Fraser River fish in their diet while feeding in the Salish Sea (Hanson et al. 2010).

Reducing uncertainty in the caloric estimates of Chinook salmon populations that are available to resident killer whales is necessary to better inform conservation and management of whales. Although Chinook salmon were sampled from 5 coastal regions spanning the documented feeding range of resident killer whales, they represent a small fraction of the Chinook salmon populations available as prey, and body size varies considerably among populations and among years within populations. We produced a simple relationship between fish body length and total energy value for use where population-specific energy content information is not available (Fig. 6). Fish length accounted for most (91\%) of the variation in kilocalories among Chinook salmon samples, and was robust, as evidenced by its consistency when any population was removed from the regression analysis (Table 4). This relationship was consistent with that of Yukon River Chinook salmon (Margraf et al. 2005). We also estimated length to kcal relationships for high- and low-fat Chinook salmon populations (based on 90th percentile values) that occur in terminal marine waters where resident killer whales feed. These high- and low-lipid values approximate energy densities for Chinook salmon with typical upstream and downstream migration patterns, respectively (Brett 1995). Consequently, the samples provided should be adequate to estimate the total energy for other popu- 
lations of interest, given their size distribution, distance, and elevation of the spawning grounds (see Figs. 4 to 6 in Quinn 2005) and information on the duration of holding in freshwater prior to spawning.

\section{Implications for conservation of killer whales and Chinook salmon}

Conservation and recovery plans have been developed for both resident killer whales (NMFS 2008a, Fisheries and Oceans Canada 2008) and Chinook salmon (NMFS 2007-2011). However, achieving conservation objectives for recovery of killer whales may conflict with the recovery objectives of Chinook salmon (Williams et al. 2011). Compared to killer whales, a wider array of management options are available to directly enhance and recover Chinook salmon because of differences in their life history. Salmon are short-lived, anadromous, impacted by habitat degradation, and the target of valuable fisheries, whereas killer whales are long-lived, unaffected by factors in freshwater habitats that are so important to salmon, and are already protected from hunting. Placing restrictions on salmon fisheries to enhance prey availability to killer whales is one option currently being evaluated by the US NMFS and Fisheries and Oceans Canada (Hilborn et al. 2012).

Improved estimates of the prey base are needed to better model the effects of possible fishery closures and other management options that affect prey availability, enhancing the integration of killer whale conservation with salmon management. The predictive relationships between fish size and caloric content for populations with a range of lipid levels presented in this paper can be used to improve estimates of the total energy value of salmon to killer whales, a gap identified by Williams et al. (2011). These estimates, in turn, will help refine estimates of the numbers of Chinook salmon (including populations not specifically sampled in our study; Ford et al. 2010b, Hanson et al. 2010) needed to support killer whales. Indeed, several recently published studies have used unpublished data from our study to estimate the number of Chinook salmon needed to meet the caloric demands of resident killer whales. Noreen (2011) and Williams et al. (2011) used the average energy value of Fraser River Chinook salmon (16386 kcal fish $\left.{ }^{-1}\right)$ that was measured in this study to estimate the number of Chinook salmon necessary to meet the energetic demands of SRKWs, assuming they consumed only Chinook salmon. Williams et al. (2011) also estimated the number of fish necessary to meet the energetic re- quirements SRKWs based on simplistic 'calorie-rich' and 'lean' Chinook salmon prey options. More recently, the Fisheries and Oceans Canada and NMFS have used the predictive relationship between fish length and caloric content for Chinook salmon presented in this study to estimate the number of Chinook salmon needed to meet the annual caloric demands of NRKW and SRKW (Ford et al. 2010b, p. 43; NMFS 2011, p. 83) throughout their feeding range.

As new information about the year-round diet of resident killer whales is revealed (summarized in Hilborn et al. 2012), including the importance of specific Chinook salmon populations and other salmon species, the predictive models between salmon size (fish length and mass) and the total energy value of a fish can be used to refine the estimates of the prey base of resident killer whales. Of particular interest, as Chinook salmon become scarce, it is important to know whether whales continue to pursue them, devoting more effort to foraging, or shift to more abundant but less energetically valuable salmon species, or other prey. Whales have been known to travel $50 \mathrm{~km} \mathrm{~d}^{-1}$ and may follow Chinook salmon long distances rather than shifting to other species. Alternatively, the ability of resident killer whales to switch prey may be constrained by their culturally inherited foraging strategies (Ford et al. 2010a). Over the long-term, the growth of resident killer whale populations may increase natural mortality of Chinook salmon. The fundamental life-history differences between salmon and killer whales will make integration of recovery plans especially challenging.

Acknowledgements. Guidance on the timing, location, and collection of fish samples was provided by the staff of the Pacific Salmon Commission (Mike Lapointe, Jim Cave, and Christine Tovey), the Canadian Department of Fisheries and Oceans (especially Ian Winther, Steve Cox Rogers, Terry Palfrey, Mike Jakubowski, and Carmen McConnell), the Washington Department of Fish and Wildlife (WDFW; Rich Lincoln and Cindy Lefleur), the California Department of Fish and Game (Melodie Palmer-Zwahlen), and the Skagit River Cooperative (Rebecca Bernard). Karl Shearer and Ronald Johnson (National Marine Fisheries Service; NMFS) provided guidance on the methodology used for proximate analysis, and Greg Lippert, Stephen Quinnell, Jonathon Hill, Michael Cotter, and Karissa Lear assisted with sample processing. Bernadita Annulacion (NMFS) produced the map. Eric Ward and Martin Liermann (NMFS) provided assistance with statistical analyses. Thomas Quinn (University of Washington) provided a wealth of guidance and direction on the appropriate literature to cite on the life history and ecology of Pacific salmon, and editorial reviews. Julann Spromberg and Alison Agness (NMFS) provided review comments on an earlier version of the manuscript. This work was funded by NMFS, Northwest Fisheries Science Center, and the WDFW. 


\section{LITERATURE CITED}

AOAC International (2000) Official Methods 942.05 (ash), 968.06 (protein) and 920.39 (lipids). Official methods of analysis of AOAC International, 17th edn. W. Howitz, Arlington, VA

Au WWL, Ford JKB, Horne JK, Allman KAN (2004) Echolocation signals of free-ranging killer whales (Orcinus orca) and modeling of foraging for Chinook salmon (Oncorhynchus tshawytscha). J Acoust Soc Am 115:901-909

Barnett-Johnson R, Grimes CB, Royer CF, Donohoe CJ (2007) Identifying the contribution of wild and hatchery Chinook salmon (Oncorhynchus tshawytscha) to the ocean fishery using otolith microstructure as natural tags. Can J Fish Aquat Sci 64:1683-1692

- Bigler BS, Welch DW, Helle JH (1996) A review of size trends among North Pacific salmon (Oncorhynchus spp.). Can J Fish Aquat Sci 53:455-465

Bowen WD, Tully D, Boness DJ, Bulheier BM, Marshall GJ (2002) Prey-dependent foraging tactics and prey profitability in a marine mammal. Mar Ecol Prog Ser 244: 235-245

Brett JR (1995) Energetics. In: Groot C, Margolis L, Clarke WC (eds) Physiological ecology of Pacific salmon. UBC Press, Vancouver, BC

> Candy JR, Quinn TP (1999) Behavior of adult Chinook salmon (Oncorhynchus tshawytscha) in British Columbia coastal waters determined from ultrasonic telemetry. Can J Zool 77:1161-1169

Dahlheim ME, Schulman-Janiger A, Black N, Ternullo R, Ellifrit D, Balcomb III KC (2008) Eastern temperate North Pacific offshore killer whales (Orcinus orca): occurrence, movements, and insights into feeding ecology. Mar Mamm Sci 24:719-729

Ewald G, Larsson P, Linge H, Okla L, Szarzi N (1998) Biotransport of organic pollutants to an inland Alaska lake by migrating sockeye salmon (Oncorhynchus nerka). Arctic 51:40-47

Fisher FW (1994) Past and present status of Central Valley Chinook salmon. Conserv Biol 8:870-873

Fisheries and Oceans Canada (2008) Recovery strategy for the northern and southern resident killer whales (Orcinus orca) in Canada. Species at Risk Act Recovery Strategy Series. Fisheries and Oceans Canada, Nanaimo

Ford JKB (1998) Dietary specialization in two sympatric populations of killer whales (Orcinus orca) in coastal British Columbia and adjacent waters. Can J Zool 76:1456-1471

Ford JKB, Ellis GM (2006) Selective foraging by fish-eating killer whales (Orcinus orca) in British Columbia. Mar Ecol Prog Ser 316:185-199

Ford JKB, Ellis GM, Balcomb KC (2000) The natural history and genealogy of Orcinus orca in British Columbia and Washington. University of British Columbia Press, Vancouver, BC

Ford JKB, Ellis GM, Olesiuk PF, Balcomb KC (2010a) Linking killer whale survival and prey abundance: food limitation in the oceans' apex predator? Biol Lett 6:139-142

Ford JKB, Wright BM, Ellis GM, Candy JR (2010b) Chinook salmon predation by resident killer whales: seasonal and regional selectivity, stock identity of prey, and consumption rates. Canadian Science Advisory Secretariat, Department of Fisheries and Oceans, Nanaimo

Gilhousen P (1980) Energy sources and expenditures in Fraser River sockeye salmon during their spawning migration. Int Pac Salmon Fish Comm Bull 22:1-51
Gustafson RG, Waples RS, Myers JM, Weitkamp LA, Bryant GJ, Johnson OW, Hard JJ (2007) Pacific salmon extinctions: quantifying lost and remaining diversity. Conserv Biol 21:1009-1020

> Hanson MB, Baird RW, Ford JKB, Hempelmann-Halos J and others (2010) Species and stock identification of prey consumed by endangered southern resident killer whales in their summer range. Endang Species Res 11:69-82

Healey MC (1991) Life history of Chinook salmon (Oncorhynchus tshawytscha). In: Groot C, Margolis L (eds) Pacific salmon life histories. University of British Columbia Press, Vancouver, BC

Henderson MA, Graham CC (1998) History and status of Pacific salmon in British Columbia. N Pac Anadr Fish Comm Bull 1:13-22

Hendry AP, Berg OK (1999) Secondary sexual characters, energy use, senescence, and the cost of reproduction in sockeye salmon. Can J Zool 77:1663-1675

Hilborn R, Cox SP, Gulland FMD, Hankin DG, Hobbs NT, Schindler DE, Trites AW (2012) The effects of salmon fisheries on southern resident killer whales: final report of the Independent Science Panel. Prepared with the assistance of D. R. Marmorek and A. W. Hall, ESSA Technologies, Vancouver, BC, for National Marine Fisheries Service (Seattle, WA) and Fisheries and Oceans Canada (Vancouver, BC)

> Hodgson S, Quinn TP (2002) The timing of adult sockeye salmon migration into fresh water: adaptions by populations to prevailing thermal regimes. Can J Zool 80: 542-555

Holt MMH, Noren DP, Viers V, Emmons CK, Viers S (2009) Speaking up: killer whales (Orcinus orca) increase their call amplitude in response to vessel noise. J Acoust Soc Am Express Lett 125:EL27-EL32

Hutchings JA, Reynolds JD (2004) Marine fish population collapses: consequences for recovery and extinction risk. Bioscience 54:297-309

> Jonsson N, Jonsson B, Hansen LP (1991) Energetic cost of spawning in male and female Atlantic salmon (Salmo salar L.). J Fish Biol 39:739-744

Jonsson N, Jonsson B, Hansen LP (1997) Changes in proximate composition and estimates of energetic costs during upstream migration and spawning in Atlantic salmon Salmo salar. J Anim Ecol 66:425-436

Krahn MM, Wade RW, Kalinowski ST, Dahlheim ME and others (2002) Status review of southern resident killer whales (Orcinus orca) under the Endangered Species Act. In: NOAA Tech Memo NMFS-NWFSC-54, US Department of Commerce, Seattle, WA

Krahn MM, Ford MJ, Perrin WF, Wade PR and others (2004) 2004 Status review of southern resident killer whales (Orcinus orca) under the Endangered Species Act. NOAA Tech Memo NMFS-NWFSC-62, US Department of Commerce, Seattle, WA

> Krahn MM, Hanson MB, Baird RW, Boyer RH and others (2007) Persistent organic pollutants and stable isotope ratios in biopsy samples (2004-2006) from southern resident killer whales. Mar Pollut Bull 54:1903-1911

Krahn MM, Bradley Hanson M, Schorr GS, Emmons CK and others (2009) Effects of age, sex and reproductive status on persistent organic pollutant concentrations in 'southern resident' killer whales. Mar Pollut Bull 58:1522-1529

Lusseau D, Bain DC, Williams R, Smith JE (2009) Vessel traffic disrupts the foraging behavior of southern resident killer whales Orcinus orca. Endang Species Res 6:211-221 
Margraf JF, Hartman KJ, Cox MK (2005) Non-lethal estimation of energy content of Yukon River Chinook salmon. Alaska Cooperative Fish and Wildlife Research Unit, Institute of Arctic Biology, University of Alaska Fairbanks, Fairbanks, AK

Myers JM, Kope RG, Bryant GJ, Teel D and others (1998) Status review of Chinook salmon from Washington, Idaho, Oregon, and California. NOAA Tech Memo NMFS-NWFSC-35, US Department of Commerce, Seattle, WA

NMFS (National Marine Fisheries Service) (2005) Endangered and threatened wildlife and plants: endangered status for southern resident killer whales. Fed Reg: 70 FR 69903

NMFS (National Marine Fisheries Service) (2007-2011) Puget Sound salmon recovery plan; Upper Columbia River salmon recovery plan; Willamette River salmon recovery plan; Lower Columbia River salmon recovery plan. NMFS, Northwest Regional Office, Seattle, WA

NMFS (National Marine Fisheries Service) (2008a) Recovery plan for southern resident killer whales (Orcinus orca). NMFS, Northwest Regional Office, Seattle, WA

NMFS (National Marine Fisheries Service) (2008b) Supplemental comprehensive analysis of the Federal Columbia River Power System and mainstem effects of USBR Upper River Snake and other tributary actions. NMFS, Portland, OR

NMFS (National Marine Fisheries Service) (2011) Endangered Species Act Section 7(a) (2) 22 Biological opinion and Magnuson-Stevens Fishery Conservation and Management Act Essential Fish Habitat Consultation. NMFS Consultation Number F/NWR/2010/06051. NMFS, Northwest Region, Seattle, WA

Nehlsen W, Williams JE, Lichatowich JA (1991) Pacific salmon at the crossroads: stocks at risk from California, Oregon, Idaho, and Washington. Fisheries 16:4-21

Noreen DW (2011) Estimated field metabolic rates and prey requirements of resident killer whales. Mar Mamm Sci 27:60-77

PFMC (Pacific Fishery Management Council) (2011) Review of 2010 ocean salmon fisheries. (Document prepared for the Council and its advisory entities.) Pacific Fishery Management Council, Portland, OR

Quinn TP (1988) Estimated swimming speeds of migrating adult sockeye salmon. Can J Zool 66:2160-2163

Quinn TP (2005) The behavior and ecology of Pacific salmon and trout. University of Washington Press, Seattle, WA

Rayne S, Ikonomou MG, Ross PS, Ellis GM, Barrett-Lennard LG (2004) PBDEs, PBBs, and PCNs in three communities

Editorial responsibility: Simon Goldsworthy,

West Beach, South Australia, Australia of free-ranging killer whales (Orcinus orca) from the northeastern Pacific Ocean. Environ Sci Technol 38: 4293-4299

Ricker WE (1972) Hereditary and the environmental factors affecting certain salmon populations. In: Simon RC, Larkin PA (eds) The stock concept in Pacific salmon, HR McMillian Lecture in Fisheries. University of British Columbia, Vancouver, BC

Ricker WE (1981) Changes in the average size and average age of Pacific salmon. Can J Fish Aquat Sci 38:1636-1656

Roni P, Quinn TP (1995) Geographic variation in size and age of North American Chinook salmon (Oncorhynchus tshawytscha). N Am J Fish Manage 15:325-345

> Ross PS, Ellis GM, Ikonomou MG, Barrett-Lennard LG, Addison RF (2000) High PCB concentrations in free-ranging Pacific killer whales, Orcinus orca: effects of age, sex and dietary preference. Mar Pollut Bull 40:504-515

Scheel D (1993) Profitability, encounter rates, and prey choice of African lions. Behav Ecol 4:90-97

Schipper J, Chanson JS, Chiozza F, Cox NA and others (2008) The status of the world's land and marine mammals: diversity, threat, and knowledge. Science 322:225-230

Seeb LW, Banks M, Beacham T, Belllinger R and others (2007) Development of a standardized DNA database for Chinook salmon. Fisheries 32:540-552

Shearer KD, Asgard T, Andorsdottir G, Aas GH (1994) Whole-body elemental and proximate composition of Atlantic salmon (Salmo salar) during the life-cycle. J Fish Biol 44:785-797

Slaney TL, Hyatt KD, Northcote TG, Fielden RJ (1996) Status of anadromous salmon and trout in British Columbia and Yukon. Fisheries 21:20-35

Stephens D, Krebs J (1986) Foraging theory. Princeton University Press, Princeton, NJ

$>$ Ward EJ, Holmes EE, Balcomb KC (2009) Quantifying the effects of prey abundance on killer whale reproduction. J Appl Ecol 46:632-640

> Williams R, Krkošek M, Ashe E, Branch TA and others (2011) Competing conservation objectives for predators and prey: estimating killer whale prey requirements for Chinook salmon. PLoS ONE 6:e26738

> Yoshiyama RM, Fisher FW, Moyle PB (1998) Historical abundance and decline of Chinook salmon in the Central Valley region of California. N Am J Fish Manage 18: 487-521

Zamon JE, Guy TJ, Balcomb K, Ellifrit D (2007) Winter observations of southern resident killer whales (Orcinus orca) near the Columbia River plume during the 2005 spring Chinook salmon (Oncorhynchus tshawytscha) spawning migration. Northwest Nat 88:193-198

Submitted: October 4, 2013; Accepted: June 27, 2014

Proofs received from author(s): October 6, 2014 